\title{
Okul Öncesi Öğretmenlerin Karakter Eğitimi Yetkinlik İnançlarının Çeşitli Değişkenler Açısından İncelenmesi
}

\author{
Erdin Burak ATA \\ Çanakkale Onsekiz Mart Üniversitesi \\ erdinburakata@gmail.com \\ ORCID: 0000-0001-6681-4363 \\ Çavuş ŞAHIN \\ Çanakkale Onsekiz Mart Üniversitesi \\ csahin25240@yahoo.com \\ ORCID: 0000-0002-4250-9898
}

\begin{tabular}{lrr} 
Araştırma Makalesi & DOI: $10.31592 /$ aeusbed.738852 \\
\hline Geliş Tarihi: 17.05 .2020 & Revize Tarihi: 01.07 .2020 & Kabul Tarihi: 16.07 .2020
\end{tabular}

\section{Atıf Bilgisi}

Ata, E. B. \& Şahin, Ç. (2020). Okul öncesi öğretmenlerin karakter eğitimi yetkinlik inançlarının çeşitli değişkenler açısından incelenmesi. Ahi Evran Üniversitesi Sosyal Bilimler Enstitüsü Dergisi, 6(2), 590-603.

\section{ÖZ}

Karakter eğitimi, öğrencilerin karakter gelişimine yardımcı olan, onların psikolojik, zihinsel özelliklerini geliştiren bir eğitim sürecidir. Karakter eğitimi, öğrencilerin demokratik ve ahlaklı olmalarını, etiği önemsemelerini, düşünce ve davranışlarını demokrasi-ahlak-etik çerçevesinde gerçekleştirmelerini sağlamaktadır. Okul öncesi dönem, karakter eğitimi için önemlidir. Okul öncesi dönemde karakter eğitiminin başarısında, öğretmen yetkinliği büyük öneme sahiptir. Bu araştırma okul öncesi öğretmenlerinin karakter eğitimi yetkinlik inanç düzeylerini belirlemek amacıyla yapılmıştır. Araştırma genel tarama deseninde gerçekleştirilmiştir. Okul öncesi öğretmenlerinin karakter eğitimi yetkinlik düzeylerini ölçmek için Kırşehir Merkez ve ilçelerde bulunan anaokulu ve bağımsız anasınıflarında görev alan 100 okul öncesi öğretmenine Milson ve Mehlig tarafından yapılan Milson ve Ekşi tarafındanTürkçe' ye uyarlanan Karakter Eğitimi Yetkinlik İnancı Skalası (KEYİS) uygulanmıştır. Araştırmadan elde edilen veriler alt gruplara ilişkin katılımeı sayısının 30'un altında olması nedeniyle nonparametrik test tekniklerinden Kruskal Wallis ve Mann Whitney U testleri kullanılmıştır. Okul öncesi öğretmenlerinin karakter eğitimi yetkinlik düzeyleri incelenirken cinsiyet, mesleki kıdem, mezuniyet durumu, çalıştıkları kurum ve yaş grubu değişkenleri incelenmiştir. Araştırma sonucunda, okul öncesi öğretmenlerinin karakter eğitimi yetkinlik inanç düzeyleri yüksek bulunmuştur. Araştırmanın sonucuna göre öğretmenlerin karakter eğitimi yetkinlik inançlarının; cinsiyet, mesleki kıdem, mezuniyet durumu, çalıştığı yaş grubuna göre değişmediği ancak öğretmenlerin çalıştığı okul türüne göre anlamlı bir farklılık gösterdiği saptanmıştır.

Anahtar Kelimeler: Okul öncesi eğitim, karakter, karakter eğitimi.

\section{Investigation of Character Education Competence Beliefs of Preschool Teachers according to Different Variables}

\begin{abstract}
Character education is an educational process that helps students develop characters and develops their psychological and mental characteristics. It enables students to be democratic and moral, to care about ethics, and to realize their thoughts and behaviors within the framework of democracy-moral-ethics. Preschool period is important for character education. Teacher competence is of great importance in the success of character education in preschool period. The research was carried out to determine the character education competence levels of preschool teachers. The research was conducted as survey research desing. In order to measure the character education competence levels of preschool teachers, the character education competence belief scale (KEYIS), which was adapted to Turkish by Milson and Ekşi by Milson and Ekşi, was applied to 100 preschool teachers working in kindergarten and independent kindergartens in Kirşehir Central and districts. Kruskal Wallis and Mann Whitney U tests, nonparametric test techniques, were used because the data obtained from the study were below 30 participants. While examining the character education competence levels of preschool teachers, gender, professional seniority, graduation status, institution and age group variables were studied. As a result of the research, character education competency belief levels of preschool teachers were found high. According to the results of the research, teachers' character education competency beliefs; It was determined that it did not change according to gender, professional seniority, graduation status, age group, but it showed a significant difference according to the type of school where teachers work.
\end{abstract}

Keywords: Preschool education, character, character education. 


\section{Giriş}

Berkowitz ve Bier (2005) karakteri karmaşık psikolojik özellikler kümesi olarak tanımlamıştır. Bir bireyin ahlaki bir etken olarak hareket etmesini, doğru olanı yapmak isteyen ve yapabilmesine yol açan özellikleri kazanmasında karakter eğitiminin etkisinden söz etmiştir. Bu özellikleri empati, şefkat, vicdan, ahlaki akıl yürütme, ahlaki değerler, ahlaki varlık, perspektif alma, ahlaki hassasiyet olarak belirtmiştir. Bireyin değer kavramlarını öğrenmesi, öğrendiği değerlerden, yeni değerler bulması, bulduğu değerleri içselleştirmesi ve benliğini bu değerlere göre düzenleyerek davranış haline getirmesi karakter eğitimi ile gerçekleşmektedir (Ersoy, 2012). Karakter eğitimi, akademik olarak başarılı bireyler yetiştirmeyi hedefleyen, insanlık tarafından kabul görüş değerleri edinmenin önemini vurgulayan, davranış ve tutumlarını söz konusu değerler çerçevesinde oluşturan bireyler yetiştirmeyi amaç edinen eğitimin genel adıdır (Katılmış, 2010). Karakter eğitimi, çocuklara temel etik değerleri kazandırmayı ana fikir edinen, bu değerleri benimseyerek hassasiyet içinde olmalarını, bunları davranışlarında göstermelerini sağlayacak etkinliklerin ve uygulamaların tamamı olarak belirtilmektedir (Meydan, 2014). Karakter eğitimi, öğrencilerin karakter gelişimine yardımcı olan, onların psikolojik, zihinsel özellikleri geliştiren, demokratik, ahlaklı ve etik düşünmelerini, davranmalarını sağlayan eğitim sürecidir.

Okul öncesi dönem, insan hayatında kullanılan birçok becerinin kazanıldığ 1 ve gelişimin kritik evrelerini kapsayan bir dönemdir. Okul öncesi eğitim problem çözme becerilerini ve bireysel özelliklerinin gelişmesi için verilen eğitimdir (Özen, 2008). Okul öncesi çağ, çocukların dil soysal ve duygusal psiko-motor ve bedensel gelişimlerine yardımcı olan eğitim programlarının kullanıldığı, toplumsal kültürel değerlerin benimsetildiği, ve çocukları ilköğretim aşamasına hazırlayan planlı ve bilinçli bir eğitim sürecidir (Balat, 2012). Okul öncesi eğitim, çocuğun doğumdan 6 yaşına kadar olan süreci, çocuktaki gelişimsel alanları ve bireysel farklılıkları dikkate alan, çocuğun potansiyelini ortaya çıkaran, kendini ifade etmesini destekleyen, yaşadığı toplumun kültürel değerlerini öğreten sistemli ve planlı eğitim sürecidir (Turaşl1, 2009). Okul öncesi eğitim dönemi, çocuğun karakter özelliklerinin şekillendiği, değerlere yönelik temellerin atıldığı, içinde yaşadığı toplumun değerler yargılarını ve kültürel yapısını öğrenmeye başladığı ilk dönemdir. Karakter, bireyin zihinsel, sosyal ve duygusal ve bedensel faaliyetlerinin sonucunda meydana gelen davranışlarına toplumun verdiği değerdir (Ekşi ve Katılmış, 2011). Kişilerin karakter özellikleri doğuştan gelmemekte olup; bireyin içinde yaşadığı aile, toplum, okul yani, sosyal ortam tarafından etkilenmektedir. $\mathrm{Bu}$ yüzden okullar, öğrencilerin hayatlarında doğru kararlar vermeleri ve doğru bireyler olmaları için onları beceri ve değerlerle donatmalıdırlar (Uysal, 2008). Bu kapsamda Türkiye'de değerler eğitimi ile ilgili araştırmaların çoğunlukla öğretmen ve öğrenciler üzerinden gerçekleştirilmektedir (Gözler, 2020). Dolayısıyla değerlerin kazandırılmasının bir eğitim durumu olduğu anlaşılmaktadır. Bireyin sağlıklı bir kişiliği olması için temel değerlerin benimsetilmesi, eğitimin başlangıç aşaması olan okul öncesi eğitimde mutlak suretle irdelenmesi gerekmektedir (Oktay, 1999).

2023 Eğitim vizyonunda değerlerden, karakterli ve ahlaklı nesiller yetiştirmekten bahsedilmektedir. Eğitim vizyonunun amacı; yaşanılan yüzyılın ve geleceğin becerilerine sahip olan ve sahip olduğu becerileri insanlık yararına sarf edebilen nesiller, bilime ilgisi, kültüre merakı ve duyarlı olan, ahlaklı kişiler yetiştirmektir. Eğitim vizyonunda sadece beceri kazandırmanın yetmeyeceği, toplumsal yaşamın içinde var olmanın da önemli olduğu belirtilmiştir. Buradan hareketle, ahlaklı bireyler yetiştirmek, bilgi ve becerilerini insanlık faydasına sunan, hayatı göğüsleyebilen, evrensel ve milli değerlerini bilen ve benimseyen nesiller yetiştirmek için karakter eğitiminin önemi ortaya çıkmaktadır (MEB, 2018).

Okul öncesi dönemde karakter eğitimi etkili bir şekilde verilmesinde, öğretmen yetkinliğinin büyük öneme sahip olduğu belirtilmektedir. Karakter eğitiminin etkili olabilmesi için öğretmenlerin, sınıf içerisinde veya dışarısında çocuğun doğruyu yanlışı öğrenmesinde etkili olmalı ve başarıya giden yolda rehber olmalıdır. Öğretmenler, birbirine saygı duyan, seven, değer veren, samimi bir sınıf ortamı oluşturmalıdır. Demokratik sınıf ortamı oluşturmalı ve değerleri öğretme konusunda öğrencilere 
firsatlar oluşturmalıdır. Öğrencilerin iş birliğini yardımlaşmasını artırmalı ve karakterlerini etkileyebilme kabiliyetlerinin olması önemlidir.

Karakter eğitiminde öğretmenlerin başarılı olabilmesi için çocukların davranışlarında değişiklik oluşturabileceği inancının fazla olması ve hedeflerini ulaşabilir koyması çok önemlidir. Karakter eğitimi hakkında yapılmış bazı çalışmalar (Berko-witz, 1999; Akt. Milson ve Ekşi, 2003; Ryan ve Bohlin, 1999) karakter eğitimi konusunda öğretmenlerin kendilerini çok yeterli görmediklerini ortaya koymaktadır. Bu çalışmanın sonucunun aksine Milson ve Mehlig (2002) karakter eğitimi konusunda öğretmenlerin yüksek düzeyde yeterli olduklarını saptamıştır. Ancak, karakter eğitimi konusunda desteğe ihtiyaç duyan öğrencileri eğitmede öğretmenlerin yetersiz olduklarını belirtmiştir (Milson ve Ekşi, 2003).

$\mathrm{Bu}$ araştırmada, okul öncesi öğretmenlerinin karakter eğitimi konusundaki yetkinliklerinin incelenmesi amaçlanmaktadır. Bu bağlamda, ilgili literatür incelendiğinde karakter eğitimi ile ilgili araştırmaların sınırlı sayıda olduğu görülmektedir (Arslan, 2019; Aslan, 2011; Avc1, 2011; Çağatay, 2009; Çatalbaş, 2018; Demirel, 2009; Emen, 2017; Karsantık ve Özgenel, 2018; Kocalar, 2019; Özbey, Türkoğlu ve Büyüktanır Buldur, 2014; Üstünyer, 2009; Yolcu, 2015; Yüksel, 2012). Bu açıdan okul öncesi öğretmenlerinin karakter eğitimi konusundaki yetkinliklerinin belirlenmesi açısından yapılan bu çalışmanın faydalı olacağı düşünülmektedir.

\section{Yöntem}

\section{Araștırma Modeli}

Araştırmada okul öncesi öğretmenlerinin karakter eğitimi yetkinlikleri çeşitli değişkenler açısından incelenmiştir. Araştırmada okul öncesi öğretmenlerinin karakter eğitimi yetkinlik inançları çeşitli değişkenlere göre incelendiği için genel tarama modeli kullanılmıştır. Genel tarama modeli; "birden fazla sayıda elemandan meydana gelmiş olan evrende, evrene dair genel bir kanıya varmak adına evrenin tamamına veya içerisinden alınan bir gurup ve örneklem üzerinde araştırma yapılmasidır" (Karasar, 2007).

\section{Evren ve Örneklem}

Kırşehir ilindeki okul öncesi eğitim kurumlarında görev yapan okul öncesi öğretmenleri araştırma evrenini oluşturmaktadır. Örneklemi ise basit tesadüfi örnekleme yoluyla seçilen 100 okul öncesi öğretmeni oluşturmaktadır. Basit tesadüfi örnekleme yöntemi, toplum hacminin 1000 'den küçük veya evreninin listeleme imkânı olduğu birimlerin homojen olduğu toplumlarda uygulanabilmektedir (Arlı ve Nazik, 2004). Örneklemde yer alan okul öncesi öğretmenlerinin; cinsiyet, yaş, kıdem durumu, mezun olduğu okul, çalıştığı okul türü, çalıştığı yaş grubu değişkenlerine göre dağılımları (betimsel istatistik sonuçları) Tablo 1'de sunulmaktadır.

\section{Tablo 1}

Okul Öncesi Öğretmenlerinin Demografik Özellikleri

\begin{tabular}{llcc}
\hline & & $\mathrm{N}$ & $\%$ \\
\hline \multirow{3}{*}{ Cinsiyet } & Kadın & 94 & 94 \\
& Erkek & 6 & 6 \\
& Toplam & 100 & 100 \\
Kidem & $1-5$ Y1l & 4 & 4 \\
& $6-10$ Yil & 36 & 36 \\
& $11-15$ Yil & 37 & 37 \\
& $16-20$ Yil & 14 & 14 \\
& 21 Yil ve üzeri & 9 & 9 \\
\hline
\end{tabular}




\begin{tabular}{llcc}
\hline & Toplam & 100 & 100 \\
& Önlisans & 3 & 3 \\
Öğrenim Durumu & Lisans & 94 & 94 \\
& Lisansüstü & 3 & 3 \\
& Toplam & 100 & 100 \\
Çalıştı̆̆ı Kurum & Anaokulu & 64 & 64 \\
& Anasınıfı & 36 & 36 \\
Yaş Grubu & Toplam & 100 & 100 \\
& 5 Yaş & 6 & 6 \\
& 5 Yaş & 32 & 32 \\
& 6 Yaş & 62 & 62 \\
& Toplam & 100 & 100 \\
\hline
\end{tabular}

Araştırmaya 94 kadın ve 6 erkek öğretmen olmak üzere toplam 100 öğretmen katılmıştır. Tabloya göre öğretmenlerin kıdem yıllarına bakıldığında; \%4'ü 1-5 yıl, \%36's1 6-10 yıl, \% 37 'si 1115 yıl, \% 14'ü 16-20 yıl ve \%9' u da 21 yıl ve daha fazla kıdeme sahiptir şeklindedir. Öğretmenlerin öğrenim durumlarına bakıldığında; \%3'ü ön lisans mezunu, \%94' ü lisans mezunu, \%3'ü de lisansüstü eğitim mezunudur. Öğretmenlerin çalıştıkları kurumlar açısından bakıldığında, \%64' ü anaokullarında, \%36' s1 anasınıflarında çalışmaktadır. Öğretmenlerin okuttukları sınıfların yaş grupları açısından bakıldığında, $\% 64$ yaş, $\% 325$ yaş, $\% 626$ yaş gruplarında çalışmaktadır.

\section{Veri Toplama Araçları}

$\mathrm{Bu}$ araştırmada "Karakter Eğitimi Yetkinlik İnancı Skalası" kullanılmıştır. Bu ölçek okul öncesi öğretmenlerinin karakter eğitimi hakkındaki algıları belirlemek adına 2002 yılında Milson ve Mehlig tarafından geliştirilmiştir. Ölçeğin Türkçe'ye uyarlamasını Ekşi (2003) yapmıştır. Ölçek 24 maddeden oluşmakta ve iki alt boyutu kapsamaktadır. Bu alt boyutlar Kişisel Öğretim Yetkinliği (KÖY) 12 madde ve Genel Öğretim Yetkinliği (GÖY) 12 maddeden oluşmaktadır. Kişisel öğretim yetkinliği, bir öğretmenin, kendisinin yetenek ve kabiliyetleri hakkındaki inancı iken Genel Öğretim yetkinliği ise öğretmenin okul ortamı, öğrencilerin aile ilişkileri gibi durumlar karşısındaki inancını ifade eder (Gibson ve Dembo, 1984).

Ölçeğin Türkçe uyarlamasında ki güvenirlik çalışmasında Ekşi (2003), KÖY için 0.83, GÖY için 0.62 Cronbach alpha değerlerine ulaşmıştır. Ölçeğe yapılan güvenirlik çalışmasında ise, ölçeğin Cronbach Alfa iç tutarlılık katsayısı "Kişisel Öğretim Yetkinliği (KÖY)" boyutu için 0.72, "Genel Öğretim Yetkinliği (GÖY)" boyutu için 0.62 olarak hesaplanmıştır. Ölçek beşli likert tipi olup, olumsuz maddeler ters puanlanmıştır. Madde seçenekleri ise "Kesinlikle Katılmıyorum (bir puan), Katılmıyorum (iki puan), Kısmen Katılıyorum (üç puan), Katılıyorum (dört puan), Kesinlikle Katılmıyorum (beş puan)" şeklindedir. Ölçekten alınacak en yüksek puan 120, en düşük puan 24 ve ölçekten alınabilecek ortalama 72 puandır. Tablo 2' de alınabilecek puanlarla ilgili bilgilere yer verilmiştir.

Tablo 2

KEYIS Puan Tablosu

\begin{tabular}{llcc}
\hline & En Yüksek & En Düşük & Ortalama Puan \\
\hline KEYİS & 120 & 24 & 72 \\
\hline
\end{tabular}




\section{Verilerin Toplanması}

Araştırmada verileri toplamak için öncelikle Kırşehir İl Milli Eğitim Müdürlüğü’nden resmi izin alınmış ve araştırmanın gerçekleştirileceği okullara gidilerek okul yönetimine ve uygulamaya katılacak olan okul öncesi öğretmenlere gerekli bilgiler verilmiştir.

Araştırmanın ölçek verilerinin toplamasında, Kırşehir il merkezi ve ilçelerinde görev yapan 100 okul öncesi öğretmenine ulaşılmıştır. Uygulama öncesi gerekli açıklamalar yapılmış ve gönüllülük esasına dayalı olduğu belirtilmiştir. Uygulama yaklaşık olarak 5 ila 10 dakikalık bir süreçte tamamlanmıştır.

\section{Verilerin Analizi}

Verilerin analizi bir istatistik programı ile gerçekleştirilmiştir. Verilerin analizinde frekans, aritmetik ortalama, yüzde ve standart sapma kullanılmış; katılımcı sayısının 30' un altında olması nedeniyle bu değişkenler, nonparametrik testlerden Mann Whitney U ve Kruskal Wallis testleri kullanılmıştır. Anlamlı farklılığı belirlemek için p değeri 0.05 olarak kabul edilmiştir.

\section{Bulgular}

Okul öncesi öğretmenlerinin karakter eğitimi yetkinlik inançlarının cinsiyet, mesleki kıdem, mezuniyet durumu, çalıştığı okul türü ve çalıştığ farklılaşmadığına ilişkin bulgulara yer verilmektedir.

\section{Okul Öncesi Öğretmenleri Karakter Eğitimi Yetkinlik İnanç Düzeylerine Yönelik Bulgular}

Anaokulu ve anasınıfında görev yapan öğretmenlerin "Karakter Eğitimi Yetkinlik İnancı Skalası (KEYİS)" na verdikleri cevapların ortalama puanları tablo 3 'te verilmiştir.

Tablo 3

Öğretmenlerin Karakter Eğitimi Yetkinlik İnanç Düzeyleri

\begin{tabular}{ccccc}
\hline & $\overline{\mathrm{x}}$ & $\mathrm{s}$ & Minimum & Maksimum \\
\hline KÖY & 48,26 & 3,94052 & 37,00 & 60,00 \\
GÖY & 43,43 & 4,07321 & 32,00 & 52,00 \\
KEYİS & 91,69 & 7,08918 & 69,00 & 112,00 \\
\hline
\end{tabular}

Tablo 3 incelendiğinde okul öncesi öğretmenlerinin ölçekten elde ettikleri ortalama puan 91.69 olduğu görülmektedir. Okul öncesi öğretmenlerin ölçeğin Kişisel Öğretim Yetkinliği (KÖY) boyutundan elde ettikleri ortalama puanın 48,26 olduğu ve Genel Öğretim Yetkinliği (GÖY) boyutundan elde ettikleri ortalamanın 43,43 olduğu görülmektedir.

Katılımcıların ölçekten aldıkları puanlar ile KEYIS' den alınabilecek ortalama puan karşılaştırıldığında, katılımcıların aldıkların puanların, ortalama puandan çok daha yüksek seviyede olduğu söylenebilir. Buradan hareketle öğretmenlerin karakter eğitimi konusunda yüksek yetkinlik inancına sahip oldukları görülmektedir.

\section{Cinsiyet Değişkenine İlişkin Bulgular}

Okul öncesi öğretmenlerin karakter eğitimi yetkinlik inancının cinsiyet değişkenine göre farklılaşıp farklılaşmadığına ilişkin gerçekleştirilen inceleme sonucu aşağıda sunulmaktadır. 


\section{Tablo 4}

Okul Öncesi Öğretmenlerinin Karakter Ĕ̈itimi Yetkinlik İnanç Düzeylerinin Cinsiyet Değişkenine Göre Incelenmesi -Mann Whitney U Testi Sonuçları

$\begin{array}{lllllll}\text { Cinsiyet } & \mathrm{N} & \text { Sira Ort. } & \text { Sira Top. } & \mathrm{z} & \mathrm{U} & \mathrm{p} \\ \text { Kadın } & 94 & 50,04 & 4703,50 & -, 635 & 238,50 & 0,526\end{array}$

KÖY

Erkek $\quad 6 \quad 57,75 \quad 346,50$

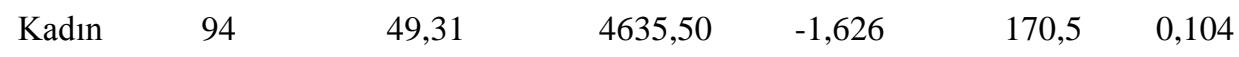

GÖY

Erkek $\quad 6 \quad 69,08 \quad 414,50$

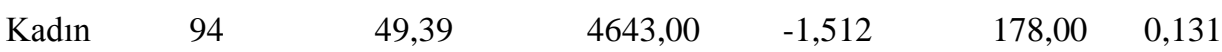

KEYIS

$\begin{array}{llll}\text { Erkek } & 6 & 67,83 & 407,00\end{array}$

Tablo 4'e göre, Kişisel Öğretim Yetkinliği (KÖY) (U=238,5, p>0.05) ve Genel Öğretim Yetkinliği (GÖY) $(U=170,5, p>0.05)$ ve KEYIS $(U=178,0, p>0.05)$ puanlarında cinsiyet değişkenine göre istatistiksel olarak anlamlı farklılık bulunmamıştır.

\section{Mesleki Kıdem Değişkene İlişsin Bulgular}

Okul öncesi öğretmenlerinin karakter eğitimi yetkinlik inançlarının mesleki kıdem değişkenine göre farklılaşıp farklılaşmadığına ilişkin gerçekleştirilen inceleme sonucu aşağıda sunulmaktadır.

\section{Tablo 5}

Okul Öncesi Öğretmenlerinin Karakter Eğitimi Yetkinlik İnanç Düzeylerinin Kldem Değişkenine Göre Incelenmesi - Kruskal Wallis Testi Sonuçlart

\begin{tabular}{|c|c|c|c|c|c|c|}
\hline & Kıdem & $\mathrm{N}$ & Sira Ort. & $\mathrm{sd}$ & $\mathrm{X}^{2}$ & $\mathrm{p}$ \\
\hline & $1-5 Y_{11}$ & 4 & 37,00 & \multirow{7}{*}{4} & \multirow{7}{*}{3,306} & \multirow{7}{*}{0,508} \\
\hline \multirow{3}{*}{ KÖY } & 6-10 Y1l & 36 & 49,01 & & & \\
\hline & 11-15 Yil & 37 & 49,58 & & & \\
\hline & $16-20 Y_{1}$ & 14 & 51,25 & & & \\
\hline \multirow{3}{*}{ GÖY } & $\begin{array}{l}21 \text { Yil ve } \\
\text { üzeri }\end{array}$ & 9 & 65,06 & & & \\
\hline & 1-5 Yil & 4 & 36,13 & & & \\
\hline & 6-10 Y1l & 36 & 46,51 & & & \\
\hline
\end{tabular}




$\begin{array}{lccccc}11-15 \text { Y1l } & 37 & 56,45 & & & \\ 16-20 Y_{11} & 14 & 43,21 & 4 & 5,054 & 0,282 \\ \begin{array}{c}21 \text { Y1l ve } \\ \text { üzeri }\end{array} & 9 & 59,72 & & & \\ \end{array}$

Tablo 5' te görüldüğü üzere okul öncesi öğretmenlerin karakter eğitimi yetkinlik düzeylerinin mesleki k1demlerine göre oluşan puan ortalamalarında Kişisel Öğretim Yetkinliği (KÖY) boyutunda "en düşük puan ortalamasını" 37,00 ortalama ile 1-5 yıllık mesleki kıdeme sahip öğretmenler oluştururken, "en yüksek puan ortalamasını" 65,06 ortalama ile 21 yıl ve üzeri mesleki kıdeme sahip öğretmenler oluşturmuştur. Genel Öğretim Yetkinliği (GÖY) boyutunda ise en düşük puanı 36,13 ile 1-5 yıllık mesleki kıdeme sahip okul öncesi öğretmenleri oluştururken, en yüksek puanı ise 59,72 ile 21 y1l ve üzeri mesleki kıdemdeki öğretmenler oluşturmuştur. Öğretmenlerin Kişisel Öğretim Yetkinliği (KÖY) ve Genel Öğretim Yetkinliği (GÖY) puanlarında kıdem değişkeni açısından anlamlı bir farklılık bulunmamaktadır (Kişisel Öğretim Yetkinliği (KÖY) p>0.05; Genel Öğretim Yetkinliği (GÖYp $>0.05$ ).

\section{Mezuniyet Durumu Değişkenine İlişkin Bulgular}

Okul öncesi öğretmenlerinin karakter eğitimi yetkinlik inanç düzeylerinin mezuniyet durumu değişkenine göre farklılık gösterip göstermediğine ilişkin gerçekleştirilen inceleme sonuçları aşağıda sunulmaktadır.

Tablo 6

Okul Öncesi Öğretmenlerinin Karakter Eğitimi Yetkinlik İnanç Düzeylerinin Mezuniyet Durumu Değişkenine Göre Incelenmesi - Kruskal Wallis Testi Sonuçları

\begin{tabular}{ccccccc}
\hline & $\begin{array}{c}\text { Mezuniyet } \\
\text { durumu }\end{array}$ & N & Sira Ort. & sd & $\mathrm{X}^{2}$ & $\mathrm{p}$ \\
\hline KÖY & Önlisans & 3 & 64,67 & 2 & 0,747 & 0,688 \\
& Lisans & 94 & 50,09 & & & \\
Lisansüstü & 3 & 49,33 & & & \\
GÖY & Önlisans & 3 & 56,50 & 2 & 0,372 & 0,830 \\
& Lisans & 94 & 50,06 & & & \\
& Lisansüstü & 3 & 58,33 & & & \\
KEYİ & Önlisans & 3 & 62,33 & 2 &, 658 & 0,720 \\
& Lisans & 94 & 49,94 & & & \\
& Lisansüstü & 3 & 56,33 & & & \\
& & & & &
\end{tabular}

Tablo 6'ya göre, okul öncesi öğretmenlerinin mezuniyet durumlarına göre Kişisel Öğretim Yetkinliği (KÖY) ( $p=0,688 ; p>0.05)$, Genel Öğretim Yetkinliği (GÖY) $(p=0,830 ; p>0.05)$ ve KEYİS $(\mathrm{p}=0,720 ; \mathrm{p}>0.05)$ puanlarında anlamlı bir farkl111k yoktur.

Okul öncesi öğretmenlerinin karakter eğitimi yetkinlik düzeylerinin mezuniyet durumu açısından bakıldığında Kişisel Öğretim Yetkinliği (KÖY) boyutunda önlisans mezunu öğretmenlerin karakter eğitimi yetkinlik inanç ortalama puanları 64,67, lisans mezunu öğretmenlerinin karakter 
eğitimi yetkinlik inanc1 ortalaması 50,09, lisansüstü mezunu öğretmenlerinin karakter eğitimi yetkinlik inanc1 ortalaması 49.33 bulunmuştur. Genel Öğretim Yetkinliği (GÖY) boyutunda ise önlisans mezunu öğretmenlerin karakter eğitimi yetkinlik inanç ortalama puanları 56,50, lisans mezunu öğretmenlerinin karakter eğitimi yetkinlik inancı ortalamas1 50,06, lisansüstü mezunu öğretmenlerinin karakter eğitimi yetkinlik inancı ortalaması 58.33 bulunmuştur.

\section{Kurum Değişkenine İlişsin Bulgular}

Okul öncesi öğretmenlerinin karakter eğitimi yetkinlik inanç düzeylerinin görev yaptıkları kurum değişkenine göre farklılık gösterip göstermediğine ilişkin gerçekleştirilen inceleme sonuçları aşağıda sunulmaktadır.

Tablo 7

Okul Öncesi Öğretmenlerinin Karakter Eğitimi Yetkinlik İnanç Düzeylerinin Kurum Değişkenine Göre Incelenmesi - Mann Whithney U Testi Sonuçları

\begin{tabular}{|c|c|c|c|c|c|c|c|}
\hline & Kurum & $\mathrm{N}$ & Sira Ort. & Sira Top. & $\mathrm{z}$ & $\mathrm{U}$ & $\mathrm{p}$ \\
\hline \multirow[t]{2}{*}{ KÖY } & Anaokulu & 64 & 47,63 & 3048,00 & $-1,328$ & 968,00 & 0,184 \\
\hline & Anasınıfi & 36 & 55,61 & 2002,00 & & & \\
\hline \multirow[t]{2}{*}{ GÖY } & Anaokulu & 64 & 46,23 & 2959,00 & $-1,969$ & 879,00 & 0,049 \\
\hline & Anasınıfi & 36 & 58,08 & 2091,00 & & & \\
\hline \multirow[t]{2}{*}{ KEYİS } & Anaokulu & 64 & 46,89 & 3001,00 & $-1,661$ & 921,00 & 0,097 \\
\hline & Anasınıfı & 36 & 56,92 & 2049,00 & & & \\
\hline
\end{tabular}

Tablo 7' ye göre, araştırmaya katılan öğretmenlerin görev yaptıkları okul türüne göre Kişisel Öğretim Yetkinliği (KÖY) (U=968,00, p>0.05) ve KEYİS (U=921,00, p>0.05) puanlarında anlamlı

farklılık bulunmamıştır. Araştırmanın çalışma grubunu oluşturan öğretmenlerin görev yaptıkları okul türü ile Genel Öğretim Yetkinliği (GÖY) puanı arasında anlamlı bir farklılık bulunmuştur (U=879,00, $\mathrm{p}<0.05)$.

\section{Öğretmenlerin Görev yaptıkları Yaş Grubu Değişkene İlişkin Bulgular}

Okul öncesi öğretmenlerinin karakter eğitimi yetkinlik inançlarının görev yaptıkları yaş grubu değiş̧kenine göre farklılık gösterip göstermediğine ilişkin gerçekleştirilen inceleme sonuçları aşağıda sunulmaktadır. 
Tablo 8

Okul Öncesi Öğretmenlerinin Karakter Eğitimi Yetkinlik İnanç Düzeylerinin Görev Yaptıkları Yaş Grubuna Göre Incelenmesi - Kruskal Wallis Testi Sonuçları

$\begin{array}{lllll}\text { Yaş } & \text { N } & \text { Sira Ort. } & \text { sd } & X^{2}\end{array}$

$\begin{array}{ccccccc}\text { KÖY } & 4 \text { Yaş } & 6 & 31,08 & 2 & 3,007 & 0,222 \\ & 5 \text { Yaş } & 32 & 53,17 & & & \\ \text { GÖY } & 6 \text { Yaş } & 62 & 51,00 & & & \\ & 4 \text { Yaş } & 6 & 42,92 & 2 & , 905 & 0,636 \\ & 5 \text { Yaş } & 32 & 53,81 & & & \\ \text { KEYİS } & 6 \text { Yaş } & 62 & 49,52 & & & \\ & 4 \text { Yaş } & 6 & 34,25 & 2 & 2,415 & 0,299 \\ & 5 \text { Yaş } & 32 & 54,19 & & & \\ & 6 \text { Yaş } & 62 & 50,17 & & & \end{array}$

Tablo 8'e göre, öğretmenlerin görev yaptı̆̆ı sınıfın yaş grubu değişkeni açısından, araştırmaya katılan öğretmenlerin KÖY, GÖY ve KEYİS puanlarında anlamlı bir farklılık bulunmamışıtır (Kişisel Öğretim Yetkinliği (KÖY) p=0,222; p >0.05; Genel Öğretim Yetkinliği (GÖY) p=0,636; p>0.05; KEYİS $p=0,299 ; p>0.05)$.

\section{Sonuç, Tartışma ve Öneriler}

Araştırmanın bu bölümünde okul öncesi öğretmenlerinin karakter yetkinlik inançlarının öğretmenlerin cinsiyetlerine, mesleki kıdemlerine, mezuniyet durumlarına, çalıştığı okul türü ve yaş grubuna göre farklılaşıp farklılaşmadığına yönelik bulguların sonuç ve tartışmasına yer verilmiştir.

Araştırmaya katılan okul öncesi öğretmenlerin karakter eğitimi yetkinlik inanç düzeyleri yüksek bulunmuştur. Kılınç Bozkurt (2019) tarafından yapılan çalışmada sosyal bilgiler öğretmenlerinin karakter eğitimine ilişkin öz-yeterlik seviyeleri yüksek bulunmuştur. Yüksel (2012) tarafından yapılan çalışmada öğretmenlerin karakter eğitimi yetkinliği ile ilgili yeterliğe sahip olduğu sonucuna ulaşılmıştır. Avcı (2011) tarafindan yapılan çalışmada sosyal bilgiler öğretmenlerinin karakter eğitimine ilişkin öz yeterlik inançları yüksek düzeydedir. Demirel (2009) tarafından yapılan çalışmada sınıf öğretmenlerinin ve yöneticilerin karakter eğitimi konusunda yeterliğe sahip olduğu sonucuna ulaşılmıştır. Milson (2003)'un yaptığı çalışma da öğretmenlerin karakter eğitimi konusunda olumlu yönde yeterlik inancına sahip oldukları görülmektedir.

Araştırmaya katılan okul öncesi öğretmenlerin karakter eğitimi yetkinlik inanç düzeylerinin, öğretmenlerin cinsiyetlerine göre anlamlı bir fark bulunmadığı saptanmıştır. Buradan hareketle okul öncesi öğretmenlerin cinsiyet durumlarının karakter eğitimi yetkinlikleri üzerinde bir etkisi olmadığı, ortaya çıkmaktadır.Araştırma sonuçları ile alanyazında karakter eğitimi ilgili yapılan çalışmalarda da benzer sonuçlara ulaşılmıştır. Kılınç Bozkurt (2019)'un çalışmasında, sosyal bilgiler öğretmenlerinin karakter eğitimi öz yeterlik düzeyi açısından kadın ve erkek öğretmenler arasında kadın öğretmenlerin lehine anlamlı farklılık olduğunu tespit etmiştir.. Emen (2017) çalışmasında, ilkokul öğretmenlerinin karakter eğitimi yetkinliklerinde cinsiyet değişkeni açısından anlamlı bir farklılık olmadı̆̆ı tespit edilmiştir. Yine Yüksel (2012)'in çalışmasında öğretmenlerin karakter eğitimi yetkinliklerinde cinsiyet değişkeni açısından anlamlı bir fark bulunmamıştır. Demirel (2009) tarafindan yapılan çalışmada da benzer sonuçlara ulaşılmış; öğretmenlerinin ve yöneticilerin karakter eğitimi yeterlikleri ile cinsiyet değişkeni arasında anlamlı bir fark bulunamamıştır. 
Araştırmaya katılan okul öncesi öğretmenlerinin karakter eğitimi yetkinlik inançlarının, öğretmenlerin mesleki kıdem durumuna göre anlamlı bir fark bulunmamıştır. Bu duruma göre öğretmenlerin mesleki kıdemlerinin karakter eğitimi yetkinlikleri ile doğrudan ilişkisi olmadığının göstergesidir. Araştırma sonuçları ve konu ile ilgili yapılan çalışmalara bakıldığında benzer sonuçların çıktığı görülmektedir. Arslan (2019) çalışmasında okul öncesi öğretmenlerinin karakter eğitimi yetkinlikleri, öğretmenlerinin kıdemlerine göre anlamlı bir fark bulunamamıştır. Karsantık ve Özgenel (2018) çalışmasında, okul yöneticilerinin karakter eğitimi yeterlik inançları, mesleki ve yöneticilik kıdemlerine göre anlamlı farklılık göstermediği saptanmıştır. Emen (2017) çalışmasında, ilkokul öğretmenlerinin karakter eğitimi yetkinliklerinin kıdem değişkeni açısından anlamlı bir farklılık olmadığı tespit edilmiştir. Özbey, Türkoğlu, Büyüktanır Buldur (2014) çalışmasında öğretmenlerin karakter eğitimi yetkinliklerinin kıdem durumuna göre anlamlı bir farklılık göstermediği saptanmıştır. Demirel (2009) tarafindan yapılan çalışmada sınıf öğretmenlerinin ve okul yöneticilerinin karakter eğitimi yeterlikleri ile kıdem değişkeni arasında anlamlı bir fark bulunamamıştır.

Araştırmaya katılan okul öncesi öğretmenlerinin mezuniyet durumları ile karakter eğitimi yetkinlikleri arasında anlamlı bir farklılık bulunmadığı saptanmıştır. Okul öncesi öğretmenlerinin mezuniyet durumları ile karakter eğitimi yetkinliklerinin anlamlı olarak farklılaşmaması, karakter eğitimi konusunda öğretmenlerin mezuniyet durumlarının bir fark oluşturmadığının göstergesidir. Araştırma sonuçları ve karakter eğitimi ile ilgili yapılan diğer çalışmalara bakıldığında mezuniyet durumu ile alakalı benzer sonuçların çıktı̆̆ görülmektedir. Arslan (2019) çalışmasında, okul öncesi öğretmenlerinin karakter eğitimi yetkinlik inancı ölçeğinden aldıkları puanlar, mezuniyet durumuna göre anlamlı bir fark göstermemektedir. Karsantık ve Özgenel (2018) çalışmasında, okul yöneticilerinin karakter eğitimi yeterlik inançları, eğitim düzeylerine göre anlamlı farklılık göstermemektedir. Özbey, Türkoğlu, Büyüktanır Buldur (2014) çalışmasında öğretmenlerin mezuniyet durumlarına göre Karakter Eğitimi Yetkinlik İnancı Skalası (KEYİS)'ten aldıkları puanlar arasında anlamlı farklılık görülmektedir. Bu farkın "Okul Öncesi Öğretmenliği mezunları ile Çocuk Gelişimi ve Eğitimi Öğretmenliği mezunları arasında ve Okul Öncesi Öğretmenliği mezunlarının lehine olduğu” saptanmıştır. Yüksel (2012) çalışmasında öğretmenlerin karakter eğitimi yetkinlikleri, mezuniyet durumuna göre anlamlı fark göstermemektedir. Demirel (2009) tarafindan yapılan çalışmada sınıf öğretmenlerinin karakter eğitimine ilişkin öz yeterlik inançları mezuniyet durumuna göre anlamlı bir fark göstermemektedir.

Araştırmaya katılan öğretmenlerin görev yaptıkları okul türü ile ölçeğin Kişisel Öğretim Yetkinliği boyutu puanı arasında anlamlı bir farklılık bulunmamıştır. Fakat araştırmanın çalışma grubunu oluşturan öğretmenlerin görev yaptıkları okul türü ile Genel Öğretim Yetkinliği puanı arasında anlamlı bir farklılık bulunmuştur. Araştırma sonuçları ve alanyazındaki karakter eğitimi ilgili yapılan çalışmalara bakıldığında benzer sonuçlar olduğu görülmektedir. Arslan (2019) çalışmasında, okul öncesi öğretmenlerinin karakter eğitimi yetkinlik inancı ölçeğinden aldıkları puanlar, görev yaptıkları kuruma göre Kişisel Öğretim Yetkinliği boyutu açısından anlamlı bir fark göstermezken, Genel Öğretim Yetkinliği boyutunda ise anlamlı fark bulunmuştur. Karsantık ve Özgenel (2018) çalışmasında, okul yöneticilerinin karakter eğitimi yeterlik inançları, görev yapılan okul kademesi değişkenlerine göre anlamlı bir farklılık göstermediği sonucuna ulaşılmıştır.

Okul öncesi öğretmenlerin görev yaptığı sınıfın yaş grubu ile öğretmenlerin Karakter Eğitimi Yetkinlik İnancı Skalası (KEYIS)'ten aldıkları puanlar arasında anlamlı bir farklılık bulunmamıştır. Okul öncesi öğretmenler görev yaptıkları kurum içerisinde belirli aralıklarla yaş grupları değişebilmektedir ve bu sebeple okul öncesi öğretmenleri kurumlarda her yaş grubundan çocuklarla iletişim ve etkileşim halindedir. Alan yazında, öğretmenlerin karakter eğitimi yetkinlik inançlarını, öğretmenlerin çalıştıkları yaş grupları açısından inceleyen bir çalışmaya rastlanmıştır. Arslan (2019) tarafından yapılan "Okul Öncesi Öğretmenlerinin Karakter Eğitimi Yetkinlik İnançları ile Yaratıcılık Düzeyleri ve İletişim Becerileri Arasındaki İlişkinin İncelenmesi” adlı çalışmada, okul öncesi öğretmenlerinin karakter eğitimi yetkinlik inancı ölçeğinden aldıkları puanlar, görev yaptıkları sınıfın yaş grubuna göre anlamlı bir fark göstermemektedir. Öneriler: 
- Araştırma okul öncesi öğretmenleri kapsamında dikkate alınacak farklı araştırma evrenlerine yönelik gerçekleştirilerek, sonuçlar karşılaştırılabilir.

- Okul öncesi öğretmenlerine karakter eğitimi konusunda eksik oldukları noktalar belirlenerek seminer, konferans ve hizmet içi eğitimler verilebilir.

Açıklamalar: $\mathrm{Bu}$ çalışma birinci yazarın 2020 yılında Prof. Dr. Çavuş Şahin danışmanlığında Çanakkale Onsekiz Mart Üniversitesi Eğitim Bilimleri Enstitüsü Temel Eğitim Anabilim Dalı'nda yürüttüğü "Okul Öncesi Öğretmenlerinin Karakter Eğitimi Hakkındaki Görüşleri ile Karakter Eğitimi Yetkinliği Arasındaki İlişki” başlıklı yüksek lisans tezinden türetilmiştir.

\section{Kaynaklar}

Arlı, P. ve Nazik, H. (2004). Bilimsel araştırmaya giriş. Ankara: Gazi Kitabevi.

Arslan, K. (2019). Okul öncesi ögretmenlerinin karakter eğitimi yetkinlik inançları ile yaratıcılık düzeyleri ve iletişim becerileri arasındaki ilişki. Yüksek Lisans Tezi, Gazi Üniversitesi Eğitim Bilimleri Enstitüsü, Ankara.

Aslan, M. (2011) Illköğretimde karakter ĕgitimi ve öğrencilere kazandırllması gereken değerler. Yüksek Lisans Tezi, Eskişehir Osmangazi Üniversitesi Eğitim Bilimleri Enstitüsü, Eskişehir.

Avc1, E. (2011). Illköğretim sosyal bilgiler öğretmenlerinin karakter ĕgitimine dair öz yeterliklerinin incelenmesi. Doktora Tezi, Gazi Üniversitesi Eğitim Bilimleri Enstitüsü, Ankara.

Balat U. (2012). Okul Öncesi eğitime giriş. Ankara: Pegem Akademi.

Berkowitz, M. (1999). Building a good person. In M. M. Williams \& E. Schaps (Eds.).Character education: The foundation for teacher education. Washington, DC: CharacterEducation Partnership and Association of Teacher Educators.

Berkowitz, M.W. and Bier, M.C. (2005). What works in character education: A researchdriven guide for educators. Washington DC: Character Education Partnership.

Çağatay, M.Ş. (2009). Öğretmen görüşlerine göre karakter eğitiminde ve gelişiminde okulun rolü. Yüksek Lisans Tezi, Çanakkale Onsekiz Mart Üniversitesi Eğitim Bilimleri Enstitüsü, Çanakkale.

Çatalbaş, M. (2018). Okul öncesi eğitim programındaki karakter eğitiminin incelenmesi ve okul öncesi ögretmenlerinin karakter eğitimi hakkındaki görüşleri. Yüksek Lisans Tezi, Kahramanmaraş Sütçü İmam Üniversitesi Sosyal Bilimler Enstitüsü, Kahramanmaraş.

Demirel, M. (2009). Sinıf öğretmenlerinin ve okul yöneticilerinin karakter eğitimine ilişkin öz-yeterlik inançları. Hacettepe Üniversitesi Ë̆itim Fakültesi Dergisi, 37, 36-49.

Ekşi, H. ve Katılmış, A. (2011). Karakter Eğitimi El Kitabı. Ankara: Nobel Yayın Dağıtım.

Ersoy, F. (2012). Sosyal Bilgiler Dersiyle bütünleştirilmiş aile katılımlı Karakter Eğitimi Programının geliştirilmesi. Yüksek Lisans Tezi. Marmara Üniversitesi. Eğitim Bilimleri Enstitüsü.

Emen, C. (2017). Illkokul öğretmenlerinin bedensel cezaya ilişkin tutumları ile karakter eğitimi yetkinlikleri arasındaki ilişki. Yüksek Lisans Tezi, Ondokuz Mayıs Üniversitesi Eğitim Bilimleri Enstitüsü, Samsun. 
Gibson, S. and Dembo, M. H. (1984). Teacher efficacy: A construct validation. Journal of Educational Psychology, 76, 569-582.

Gökçek, B. S. (2007). 5-6 yaş çocukları için hazırlanan Karakter Eğitimi Programının etkisinin incelenmesi. Doktora Tezi, Marmara Üniversitesi Eğitim Bilimleri Enstitüsü, İstanbul.

Gözler, A. (2020). Değerler Eğitimi Kapsamında Hazırlanan Akademik Çalışmaların Farklı Değişkenler Göre İncelenmesi. Ahi Evran Üniversitesi Sosyal Bilimler Enstitüsü Dergisi, 6(1), 224-241.

Karasar, N. (2014). Bilimsel araştırma yöntemi (26. Baskl). Ankara: Nobel Akademik Yayıncılık.

Karsantık, İ. ve Özgenel, M. (2018). Okul yöneticilerinin Karakter Eğitimi yeterlik inançlarının bazı değişkenlere göre incelenmesi, Değerler Eğitimi Dergisi, 16 (35), 211-233.

Katılmış, A. (2010). Sosyal bilgiler derslerindeki bazı değerlerin kazandırılmasına yönelik bir karakter eğitimi programının geliştirilmesi. Doktora tezi, Marmara Üniversitesi Eğitim Bilimleri Enstitüsü.

K1lıç Bozkurt, D. (2019). Sosyal bilgiler öğretmenlerinin karakter eğitimine ilişkin öz-yeterliklerinin incelenmesi. Yüksek Lisans Tezi, Nevşehir Hacı Bektaş Veli Üniversitesi, Sosyal Bilimler Enstitüsü, Nevşehir.

Kocalar, E. (2019). 2013 Okul Öncesi Eğitim Programının Karakter Eğitimi Açısından Değerlendirilmesi. Yüksek lisans tezi, Gaziantep Üniversitesi Eğitim Bilimleri Enstitüsü.

Lickona, T. (1997). The teacher's role in character education. The Journal of Education, 179(2), 63-80.

Meydan, H. (2014). Okulda Değerler Eğitiminin Yeri ve Değerler Eğitimi Yaklaşımları Üzerine Bir Değerlendirme, BEÜ İlahiyat Fakültesi Dergisi, 1(1). s. 93-108.

Millî Eğitim Bakanlığı. (2018). 2023 Eğitim Vizyon Belgesi. Ankara.

Milson, A, J. ve Ekşi, H. (2003). Öğretmenlerin Karakter Eğitiminde yetkinlik duygusu konusunda bir ölçme aracına doğru: Karakter Eğitimi Yetkinlik Inancı Skalası (KEYİS) ve Türkçe’ye uyarlanma çalışması (electronik versiyonu). Değerler Eğitimi Dergisi, 1 (4), 99-130.

Oktay, A. (1999). Yaşamın sihirli yılları: Okul Öncesi Dönem. Ankara: Epsilon Yayınevi.

Özbey, S., Türkoğlu, D. ve Büyüktanır Buldur, A. (2014). Okul öncesi öğretmenlerinin karakter eğitimi yetkinlik inançlarının öğretmenlerin çocuk sevme düzeyleri ve bazı değişkenler ile ilişkisinin incelenmesi. Değerler Ĕ̆itimi Dergisi, 12(27), 323-344.

Özen, Ş. (2008). Okul Öncesi Eğitim ve aile: Anne ve babaların Okul Öncesi Eğitimden beklentileri (Kars ili örneği). Sosyal Bilimler Enstitüsü, Kafkas Üniversitesi, Kars.

Ryan, K. and Bohlin, K. (1999). Building character in scholls pratical ways to bring moral instruction to life. San Francisco: Jossey-Bass.

Turaşlı, K. N. (2009). Okul Öncesi Eğitimin Tanımı, Kapsamı ve Önemi. G. Haktanır (Ed.), Okul Öncesi Eğitime Giriş, Anı Yayıncılık, Ankara.

Uysal, F. (2008). Karakter eğitimi programının değerlendirilmesi, Yüksek lisans tezi, Marmara Üniversitesi, İstanbul. 
Üstünyer, F. (2009). Karakter eğitimi ile ilgili eğitimcilerin görüşleri üzerine nitel çalışma. Yüksek Lisans Tezi, Yeditepe Üniversitesi Sosyal Bilimler Enstitüsü, İstanbul.

Yolcu, E. (2015). Karakter eğitiminde öğretmen niteliklerinin ve öz yeterlik algllarının incelenmesi. Yüksek Lisans Tezi, Çukurova Üniversitesi Eğitim Bilimleri Enstitüsü, Adana.

Yüksel, G. (2012). İlköğretim öğretmenlerinin karakter ĕgitimi yetkinlik inançları ile ahlaki olgunluk düzeyleri arasındaki ilişsi. Yüksek Lisans Tezi, Eskişehir Osmangazi Üniversitesi Eğitim Bilimleri Enstitüsü, Eskişehir. 



\section{Extended Abstract}

\section{Introduction}

Many skills used in human life are gained in preschool period. It is a period that covers the critical stages of development. In this period, the character traits of the child are shaped and the values and cultural structure of the society in which they live are started to be learn. Character traits of individuals are not innate and are affected by the family, community, school, social environment in which the individual lives. Therefore, schools must equip students with skills and values to make the right decisions in their lives and become the right individuals (Uysal, 2008). Character education is the education process that helps students develop characters, develop their psychological, mental characteristics, and enable them to think, act, be democratic, moral and ethical. It is stated that teacher competence is of great importance in providing character education effectively in preschool period. In order for character education to be effective, teachers must be effective in learning the right and wrong of the child in the classroom or outside the classroom and should be a guide on the way to success. In this study, it is aimed to examine the competencies of preschool teachers on character education. Character education competence levels of preschool teachers were examined in the context of gender, professional seniority, graduation status, institution (type of school) and age. In this context, when the literature is analyzed, it is seen that there is a limited number of studies on character education. In this respect, it is thought that this study will be beneficial in order to determine the competencies of preschool teachers on character education.

\section{Method}

In the study, the character education competencies of preschool teachers were examined based on various variables. Survey model was used in the research. The research universe is consist of preschool teachers working in Kırşehir. The sample consists of 100 pre-school teachers working in Kırşehir, which was selected by simple random sampling. "Character Education Competence Belief Scale" was used as data collection tool. In the reliability study of the scale, the Cronbach Alpha internal consistency coefficient of the scale was calculated as 0.72 for the "Personal Teaching Competence" dimension and 0.62 for the "General Teaching Competence" dimension. The highest score to be obtained from the scale is 120 , the lowest score is 24 and the average score that can be obtained from the scale is 72 points. SPSS 21 program was used for data analysis. In the analysis of data, mean and standard deviation were used for descriptive analysis; Mann Whitney $U$ and Kruskal Wallis tests, which are nonparametric tests, were used for difference analysis. To determine the significant difference, $\mathrm{p}$ value was accepted as 0.05 .

\section{Result, Discussion and Conlusion}

It can be said that the scores received by preschool teachers are much higher than the average score. From this point of view, it is seen that teachers have high competence belief in character education.

There was no significant difference in Personal Teaching Competency scores according to gender variable. There was no statistically significant difference according to gender variable in General Education Competence scores.

There was no significant difference in terms of seniority of teachers' Personal Teaching Competency and General Teaching Competency scores.

There is no significant difference in the Personal Education Competence and General Teaching Competency scores of preschool teachers in terms of their graduation status. 
There was no significant difference in the Personal Education Competency scores of the teachers in terms of the type of school they work. A significant difference was found in terms of the type of school in which teachers worked in the General Teaching Competency scores.

There is no significant difference in terms of the age group of the class in which teachers work in Personal Teaching Competency and General Teaching Competency scores.

Preschool teachers' character education competencies are high. Gender, seniority, graduation level, "age group of the class in which they work" variables do not affect the character education levels of teachers. Only the "type of school" variable affects General Education Competence. However, the variable of "type of school" does not affect Personal Teaching Competence.

According to the results of the research, the following suggestions are included:

- Teachers can be given lessons related to character education in their postgraduate education in order to develop their character education competencies.

- Seminars, conferences and in-service trainings can be given to preschool teachers by identifying their deficiencies in character education.

- To determine character education competence beliefs, studies can be conducted not only with preschool teachers but also with school administrators and other branch teachers. 